Олексин I. I., irina-oleksin@ukr.net, ORCID ID: 0000-0001-9118-8173,

Researcher ID: F-7306-2019,

к.е.н., дои., доцент кафедри підприємництва, торгівлі та логістики, Львівський торговельноекономічний університет, м. Львів

\title{
МІСЦЕ ТА РОЛЬ ОПЦІОННИХ ОПЕРАЦІЙ НА РИНКУ ФІНАНСОВИХ ДЕРИВАТИВІВ
}

\begin{abstract}
Анотація. У статті розглянуто основні характерні особливості опиіонних контрактів як розповсюджених та порівняно нових інструментів на світовому та українському ринках фінансових деривативів. Особливу увагу приділено можслвостям застосування опціонів та опціонних контрактів практично вітчизняними фінансовими закладами. Дослідження трунтуються на зарубіжному досвіді провідних краӥн світу, в яких розглянуті фінансові інструменти відіграють значну роль у процесі страхування фінансових та валютних ризиків. Доведено, щзо похідний фінансовий інструмент опціон як економічне явище передбачає консенсус інтересів контрагентів угоди на основі асиметрії їх прав і обов'язків. Певний інтерес викликає класифікація опціонів, розроблена автором на основі літературних джерел та власних досліджень. На основі аналізу характерних ознак опціонних угод розглянуто варіант встановлення цінових меж для опціонів “кол”. Зазначено, щчо відмінною особливістю бар'єрних опціонів є наявність додаткового параметра - тригера, який визначає наявність або відсутність прав на здійснення угоди. Аналіз спеціальної літератури дозволив констатувати, щзо для ефективного застосування середніх опціонів необхідно мати максимум інформації про минулу та поточну ринкову кон'юнктуру. Наголошено, щуо опціон є одним із найбільи використовуваних фінансових інструментів для хеджування та виокремлено сукупність його модифікаџій. У процесі дослідження операцій із процентними опџіонами виявлено ряд закономірностей та зворотних взаємозалежностей між ставками прибутковості та цінами на боргові ичінні папери. Подальші дослідження мають спрямовуватися на розробку стратегічних напрямів розвитку ринку фінансових деривативів, зокрема розширення інструментарію строкового ринку та посилення нормативно-правового регулювання.
\end{abstract}

Ключові слова: актив, біржа, деривативи, контракт, опціон, кол, пул, ринок, спот, страйк, тригер, угода, фінансові інструменти, хеджування.

Oleksyn I. I.,

Ph.D., Associate Professor, Associate Professor of the Department of Entrepreneurship, Trade and Logistics, Lviv University of Trade and Economic, Lviv

\section{PLACE AND ROLE OF OPTIONAL OPERATIONS IN THE FINANCIAL DERIVATIVES MARKET}

\begin{abstract}
The main features of option contracts as widespread and relatively new instruments in the global and Ukrainian financial derivatives markets are considered in the article. Particular attention is paid to the possibilities of using options and option contracts in almost domestic financial institutions. The research is based on the foreign experience of the world's leading countries, where the considered financial instruments play a significant role in the process of insuring financial and currency risks. It is proved that the derivative financial instrument option, as an economic phenomenon involves the consensus of interests of the parties to the agreement based on the asymmetry of their rights and obligations. Of particular interest is the classification of options developed by the author on the basis of literature sources and his own research. Based on the analysis of the characteristic features of option agreements, the option of setting price limits for call options was considered. It is noted that a distinctive feature of barrier options is the presence of an additional parameter - the trigger, which determines the presence or absence of rights to exercise the agreement. An analysis of the special literature revealed that in order to effectively use medium options, it is necessary to have maximum information about past and current market conditions. It is emphasized that the option is one of the most utilized financial instruments for hedging and a set of its modifications is singled out. In the process of researching operations with interest rate options revealed a number of patterns and inverse relationships between rates of
\end{abstract}




\section{Herald of Lviv University of Trade and Economics. Economic Sciences. № 65, 2021}

return and prices for debt securities. Further research should be focused on developing strategic directions for the development of the financial derivatives market, in particular, expanding the tools of the futures market and strengthening regulatory framework.

Keywords: asset, exchange, derivatives, contract, option, call, pool, market, spot, strike, trigger, deal, financial instruments, hedge.

JEL Classification: G20; G24; L81; O16

DOI: https://doi.org/10.36477/2522-1205-2021-65-14

Постановка проблеми. Одним із важливих i багатофункціональних інститутів ринку слід визнати біржу, яка забезпечує функціонування ринку шляхом створення умов і опосередкування обміну в товарно-грошовій формі, тобто являє собою сферу організованої торгівлі. Це дає підставу для твердження, що біржові інститути відіграють системотворчу роль у становленні та розвитку національних та світових ринків. Саме біржова торгівля - найбільш близький до ідеалу приклад ринкової системи, де у повній мірі проявляються закони конкуренції, попиту та пропозиції, здійснюється справедливе ціноутворення. Хоча від часу свого виникнення біржові інститути зазнали значні зміни, їх розвиток має пріоритетний вплив для еволюції ринкової економіки та формування їі сучасного виду. Зазначимо, що першочергово основним об'єктом біржової торгівлі був реальний товар. Однак поступово біржа перетворювалася 3 торгового на фінансовий інститут, головною метою якого стало створення фінансово-інформаційної інфраструктури та зниження рівня витрат. Це сприяло популяризації серед професійних гравців та приватних інвесторів опціонних операцій. Крім традиційних стратегій, опціони широко використовуються біржовими трейдерами та хеджерами для страхування своїх позицій, а також для реалізації арбітражу, тобто гри на цінових дисбалансах.

Визначення місця опціонних операцій у системі біржової торгівлі становить особливий інтерес як із юридичної, так і з економічної точок зору. Так, постановка цієї проблеми безпосередньо пов'язана 3 визначенням правової природи опціонного контракту та структури біржового ринку фінансових деривативів. Дана проблематика має прикладне значення і полягає насамперед у доцільності застосування положень законодавства, що регулює біржову торгівлю, зокрема застосування опціонів та опціонних контрактів вітчизняними фінансовими закладами.

Аналіз останніх досліджень і публікацій. Основи теорії функціонування ринку деривативів сформували такі класики економічної науки, як Дж. М. Кейнс, Дж. Хікс, І. Фішер та ін. Подальшого розвитку операції 3 похідними фінансовими інструментами набули в наукових працях відомих західних економістів Ф. Блека, Р. Колба, Дж. Маршалла, Р. Мертона, М. Мілера, Ф. Модільяні, М. Скоулза, Дж. Фіннерті, С. Х’юза, В. Шарпа, Ф. Шварца та ін. Проблематикою розвитку вітчизняного ринку деривативів почали займатися порівняно недавно, грунтовні дослідження провели у працях Т. Андросовича, М. Гапонюк, О. Парандій [11], М. Диба, А. Бєгун, О. Білошицький, Є. Поліщук [12], В. Зельдіс [6], І. Бурденко, Н. Дегтярьова, Ю. Коваленко [9], О. Колодізєва, О. Коцюба [7], І. Кицюк, Г. Коваль, В. Міщенко, Л. Примостка, М. Солодкий [1], О. Сохацька [4], О. Сидоренко [13], О. Шевченко [8], В. Шелудько, В. Вірченко [5] та ін. Вони зосереджують свою увагу на таких аспектах, як еволюція формування ринку, перспективи розвитку українського ринку деривативів, тенденції світового ринку, законодавчі аспекти тощо. Втім, низка питань залишається невирішеною та потребує подальшого розгляду 3 урахуванням нових тенденцій і умов, що склалися iз запровадженням строкових інструментів у практику функціонування вітчизняних бірж.

Постановка завдання. Основною метою статті є обгрунтування місця та дослідження ролі опціонних операцій на ринку фінансових деривативів, а також виявлення особливостей їх правового регулювання.

Виклад основного матеріалу дослідження. Опціонний контракт надає право, проте не зобов'язує купити (кол-опціон) або продати (путопціон) базовий інструмент за визначеною ціною ціною виконання (страйк) - та обумовленою датою. Опціони застосовуються учасниками ринку 3 метою: 1) хеджування та захисту від несприятливих цінових змін на базовий інструмент; 2) спекуляції на зростанні (зниженні) ринкової ціни базового активу; 3) здійснення арбітражних операцій на строковому ринку та з різними інструментами.

Похідний фінансовий інструмент “опціон” як економічне явище - це взаємоузгоджені відносини учасників, які скеровані на здійснення окремих функцій похідних фінансових інструментів, що грунтуються на асиметрії прав і обов'язків двох контрагентів угоди.

У науковій літературі окремі вчені трактують опціон як “... цінний папір (контракт), що містить право (але не обов'язок): купити, продати зафіксований обсяг любих товарів, валюти, цінних паперів, у тому числі похідних (або відмовитися від угоди), протягом передбаченого строку за встановленою ціною; отримати визначений дохід від фінансового вкладення або грошової позики у вигляді різниці, фіксованого розміру, відсотку" [1].

Опціони різняться за базисами, що в їх основі (акції, валюта, відсотки, товари тощо). Частину ринку, яка самостійно розвивається, складають 
опціони на: 1) ф’ючерси; 2) свопи; 3) опціони. Для всіх опціонів незалежно від базису є притаманними єдині структурні ознаки-характеристики, котрі дозволяють виявити побудову даного типу похідних продуктів-інструментів.

У світовій практиці розрізняють два види опціонів:

- опціон на покупку (опціон покупця) - кол (call option - право покупця отримати від продавця опціону базисний актив у зафіксованому на майбутне часі за твердо встановленою ціною);

- опціон на продаж (опціон продавця) - пут (put option - право покупця опціону продати продавцю опціону базисний актив у зафіксованому на майбутнє часі за твердо встановленою ціною).

У науковій літературі існує велика сукупність різновидів опціонів пут та кол, які досі остаточно не досліджені. На наш погляд, найбільш коректним $\epsilon$ групування опціонів у чотири класи, кожний із яких слід поділити на види, різновиди та стилі (табл. 1).

Пут або кол у найбільш простому виконанні потрапляють до класу ванільних опціонів, які мають два стиля (американський та європейський). Опціони даного класу є класичними, тобто ванільні опціони - це звичайні кол та пут опціони. Важливим моментом в опціонних угодах $€$ визначення чітких цінових меж для опціонів. На рис. 1 запропоновано варіант із опціонами “кол" та встановлення його цінових меж.

Другий клас представлений бар'єрними опціонами (в економічній літературі ці опціони називаються також тригер-опціонами (trigger options), опціонами кат-оф (cut-off options), стопціонами (stoptions), опціонами нок-апс (knockups) [4, с. 84].

Відмінна особливість даних опціонів полягає в наявності додаткового (окрім страйку, базисного активу та дати завершення) параметра - тригера (trigger), який визначає наявність або відсутність прав на здійснення угоди. Це передбачає досягнення цінового рівня, за якого зумовлені опціонним контрактом права виникають або зникають у повному обсязі (у випадку не досягнення тригера права по опціону не можуть бути виконані або змінені в залежності від класу бар'єрного опціону). Бар'єрні опціони в процесі проходження тригера (або до нього) перетворюються в звичайні європейські опціони.

Класифікація видів опціонів

Табличя 1

\begin{tabular}{|c|c|c|c|}
\hline Клас & Вид & Різновид & Стиль \\
\hline Бар'єрні (Bater options) & $\begin{array}{l}\text { Пут } \\
\text { Кол }\end{array}$ & $\begin{array}{c}\text { Knok - in Knok - out } \\
\text { Revers Knok - Revers } \\
\text { Knok - out }\end{array}$ & $\begin{array}{c}\text { Американський } \\
\text { Свропейський }\end{array}$ \\
\hline $\begin{array}{c}\text { Оптимальні (Optimal op- } \\
\text { tions) }\end{array}$ & $\begin{array}{l}\text { Пут } \\
\text { Кол }\end{array}$ & Optimal Strike optimal Rate & $\begin{array}{c}\text { Американський } \\
\text { Свропейський }\end{array}$ \\
\hline $\begin{array}{c}\text { Пут } \\
\text { Кол }\end{array}$ & Average Strike Average Rate & $\begin{array}{c}\text { Американський } \\
\text { Свропейський }\end{array}$ \\
\hline
\end{tabular}

Джерело: складено автором за [2 та 3]

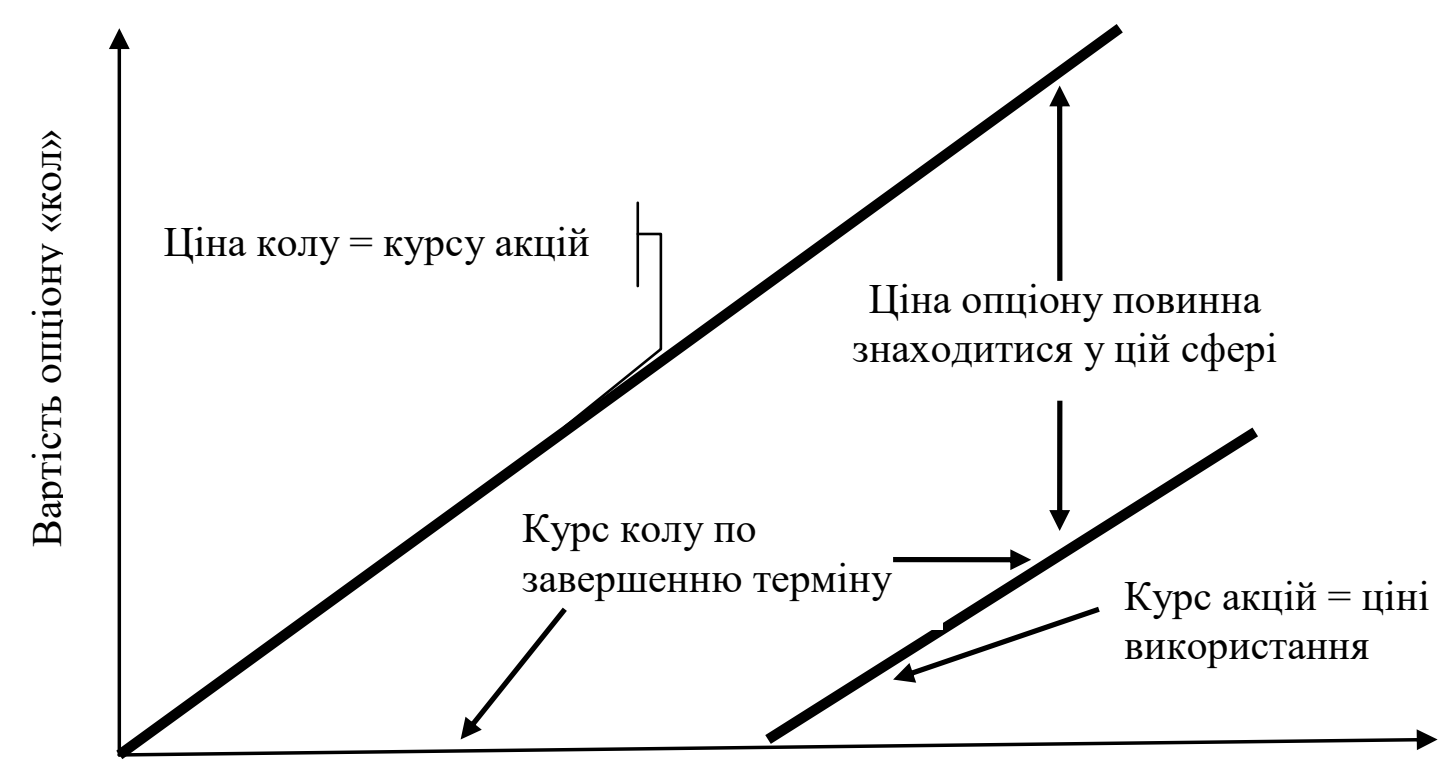

0

Курс акцій після завершення терміну опціону

Рис. 1. Цінові межі опціонів "кол"

Джерело: побудовано автором за [5] 


\section{Herald of Lviv University of Trade and Economics. Economic Sciences. № 65, 2021}

Розрізняють наступні класи бар'єрних опціонів: 1) опціони нок-ин (in - options, or knock - in option); 2) опціони нок-аут (out - option, or knock - in option); 3) зворотні нок-ин (reverse knock - in); 4) зворотні нок-ин (reverse knock - out) [6].

Враховуючи характеристики бар'єрних опціонів, їх застосування досить привабливе для українських фінансових закладів. Проте на вітчизняному ринку фінансових деривативів їх використання - обмежене. На практиці розрізняють ряд термінів, пов'язаних із бар'єрними опціонами. Так, коли тригер зупиняється в зоні “поза грошима" на ринку спот, мова йде про стандартний бар'єрний опціон. У зворотному бар'єрному опціоні тригер розташовують в зоні “у грошах" на ринку спот. Якщо у стандартному бар'єрному опціоні тригер знаходиться поміж страйком та поточним курсом спот, то це “оснащений” бар'єрний опціон - синонім терміна, який застосовується при використанні важеля.

Існує ще один клас опціонів, що розроблений як похідний від оптимальних опціонів і має назву середній опціон. Виокремлюють дві різновидності середніх опціонів: 1) середній страйк; 2) середній курс [7, с. 243]. У середньому опціоні страйком виступає середнє значення ринкової ціни активу за певний проміжок часу, який залежить від строку його дії. При укладанні угоди фіксують не тільки об'єкт опціону та строк його дії, але й період усереднення та метод розрахунку середньої величини (проста середня, зважена тощо). Для результативного застосування середніх опціонів необхідно мати максимум інформації про поточний стан ринку, а також про його історичний розвиток. Середній курсовий опціон ідентичний оптимальному курсовому опціону та середнє значення ринкових цін, розраховане обумовленим способом, стає ціною, яка визначає розмір премії.

Оскільки в процесі змін поточного курсу базового активу відкриваються нові опціони, то одночасно для ідентичних активів можуть існувати декілька різних опціонів. Всі опціони одного виду (пут та кол) прийнято називати опціонним класом [8, с. 14]. Опціони одного класу з єдиним страйком та датою закінчення контракту утворюють опціонну серію.

Слід відзначити, що існуючі класи різновидностей опціонів не обмежуються вищепереліченими видами опціонів. На позабіржовому ринку спостерігаються нестандартні контракти, поява яких стала можливою завдяки прагненню фінансових закладів прилаштуватися до вимог клієнтів. Кількість різновидностей опціонів, які застосовують на світовому ринку визначити досить складно, адже вони постійно збільшуються. Враховуючи, що опціон $\epsilon$ одним із найбільш використовуваних фінансових інструментів для хеджування різного роду позицій та ризиків, цілковито природною $є$ наявність сукупності інших модифікацій:

- Бостонський опціон - це американський опціон, за якого виплата премії відбувається пізніше та закладається в значення страйку у випадку виконання опціону, а при невиконанні - премія виплачується після закінчення. Даний опціон відомий також як капіталізований опціон або форвардний зворотний опціон $[9$, с. 91];

- подвійний опціон - це комбінація “кол” та “пут”, яка дає право покупцю купити або продати базисний актив за визначеною ціною в майбутньому;

опціон "BERO" (bearer exchange rate option) - це дрібно номінований валютний опціон: долар або фунт; долар або марка, який виписується "Barclays Bank" [9, c. 135];

- опціон “кванто" (quanto-option) - валютний опціон, яким торгує “Goldman Sachs”, дозволяє змінити суму іноземної валюти в цілях відповідати вимогам [10].

У залежності від ступеня покриття позиції опціони поділяються на покриті та не покриті. Чиста купівля або продаж останніх означає, що у випадку несприятливого розвитку кон'юнктури вкладник зазнає втрат. Проте певною мірою ризик втрат виключається за рахунок додаткової купівлі або продажу активів, які знаходяться в основі опціону, тобто його покриттям (позиція вважається хеджованою). Отже, райтер опціону кол 3 поставкою, який має певну кількість базисного активу або має наміри придбати його в момент постачання (у випадку виконання контракту), вважається тим, хто виписав покритий кол.

На нашу думку, умови постачання таких опціонів є досить специфічними. Опціон із фізичним постачанням товару надає його власнику право отримати по поставці (кол) або поставити (пут) базовий актив у процесі виконання опціону за обумовленою в контракті базовою ціною (страйк), а продавцю - обов'язок здійснити дану угоду з власником опціону незалежно від поточної ринкової ціни базисного активу. Також розрізняють опціони: 1) розрахунковий; 2) із фізичним постачанням [11, c. 127].

Процентні опціони, опціони за процентними ставками - ще один із способів захисту від несприятливої динаміки коливань процентної ставки. Цей контракт торкається тільки руху ставок та не стосується власних кредитів або позик, використовуваних як позичальниками, так і інвесторами.

Розрахунковий опціон надає право його власнику отримувати готівковий платіж. Розрахункова сума - це різниця, на яку розрахункова ціна базисного активу, за розрахунковим опціоном кол, перевищує ціну виконання або на яку страйк розрахункового опціону пут перевищує розрахункову ціну (тобто дорівнює різниці між визначеною ціною базового активу під час виконання опціону та страйком опціону), помножена на кількість контрактів у відповідній валюті, в якій сплачується розрахункова сума (розрахункова валюта). Спосіб визначення розрахункової ціни на конкретні види опціонів фіксується в правилах кожного опціонного ринку та може варіювати від ринку до ринку та зазнавати змін під впливом різних чинників.

У процесі дослідження операцій із процентними опціонами виявлено ряд закономірностей та зворотних взаємозалежностей між ставками 
прибутковості та цінами на боргові цінні папери. Базисними активами для процентних опціонів $\epsilon$ державні боргові цінні папери. Залежність величини премій за опціонами, які базуються на цінах, а також від змін цін та ставок представлено в табл. 2.

Всі опціони, які базуються на прибутковості, це, як правило, розрахункові європейські опціони. Базисним активом для них $є$ річна прибутковість стосовно погашення вищеперелічених паперів, розрахована за цінами відповідно до методики торговельного майданчика, на якому обертаються опціонні контракти, а у випадку казначейських векселів - річний дисконт за ними. Базисна прибутковість встановлюється у відсотковому вираженні прибутковості, помноженому на десять.

Специфічна риса процентних опціонів - залежність премії опціону від очікуваних ставок у майбутньому на строк закінчення контракту. Ставки прибутковості, що очікуються на ринку для більшості останніх траншей на дату закінчення, називають форвардними ставками [12, с. 387]. Якщо ринок прогнозує форвардні ставки на рівні нижче від поточних, то опціони кол будуть падати, а опціони пут - зростати в ціні. Феномен форвардних ставок може проявлятися лише на короткому відрізку кривої прибутковості. Різниця між поточною та форвардною ставками може бути значною та залежати від сегмента кривої прибутковості.

При очікуванні низьких форвардних ставок опціони кол можуть пропонуватися нижче від своєї внутрішньої вартості. При цьому премія за контракти 3 більш далекими позиціями може бути нижчою за премію для контрактів із близькими термінами виконання. Отже, внаслідок перегляду трейдерами своїх очікувань ціни опціонів можуть різко змінюватися навіть за умови незмінності поточних ставок.

Спочатку процентними опціонами займалися, як правило, страхові компанії, але з часом ці операції почали застосовувати фінансові установи. За останні десятиліття на ринку з'явилося безліч різноманітних типів опціонів, що отримали назву кеп, флор і колар, а також їх варіації та конструкції [13].

Своєрідну міру цін для групи цінних паперів прийнято трактувати як індексні опціони [4, с. 98]. Фондові індекси спеціально розроблені для різних фінансових інструментів (акцій, державних цінних паперів, іноземних валют тощо). Проте сьогодні вони $є$ найбільш розповсюдженими та слугують основним базовим активом для опціонів. Фондові індекси складаються та публікуються різними джерелами, у тому числі торговельними майданчиками. Індекси відображають стан національного фондового ринку та цінних паперів як для окремих торговельних майданчиків, так і для його секторів, які діють у різних галузях національного господарства. Вони можуть грунтуватися на цінах всіх або частини запропонованих акцій. Фондовий індекс виражається відношенням до бази, яку затверджують при створенні індексу й яка час від часу змінюється для відображення змін у капіталізації паперів, що входять до неї (додавання або вибуття окремих паперів).

Поправки вносяться для того, щоб зміни у значенні індексу були викликані лише змінами цін акцій протягом торговельного дня. Виключення акцій зі складу індексу може бути викликано злиттям або ліквідацією відповідних підприємств або їх невідповідністю умовам включення до індексу. Зміни в основі індексу додавання та виключення цінних паперів знаходяться в компетенції видавця індексу та зазвичай не викликають жодних змін в умовах опціонів, що обертаються на індекс. Оскільки цей процес може істотно вплинути на рівень індексу, то ці зміни має право здійснити видавець (розробник методу обчислення індексу). Слід враховувати, що індекс миттєво реагує на рух цін.

Валютні опціони - гнучкий інструмент покриття валютних ризиків - використовуються з метою захисту від втрат, пов'язаних із коливаннями валютних курсів. Вони $є$ контрактами на купівлю або продаж однієї валюти за ціною, вираженою в іншій валюті, відомі в економічній літературі як обмінний валютний курс [9, с. 412]. Іншими словами, валютний курс - страйк валютного опціону. Валюта, в якій виражені премія і страйк, називається базовою валютою, а валюта, яка купується або продається, базисною валютою. Опціони на купівлю або продаж однієї іноземної валюти за ціною, вираженою в іншій іноземній валюті, називаються опціонами на крос-курс, оскільки їхній страйк - це крос-курс [9, c. 405].

До опціону на крос-курс застосовують всі загальні положення стосовно валютних опціонів, за виключенням тих, що стосуються доларових валютних опціонів. Кількість інвалюти, що покриває даний опціон (тобто торговельна одиниця), визначається безпосередньо опціонним ринком.

Таблиця 2

Залежність величини премій за опціонами, що базуються на цінах

\begin{tabular}{|l|c|c|c|}
\hline \multicolumn{1}{|c|}{ Показник } & Ціни & Кол & Пут \\
\hline Залежність величини премій за опціонами, що базуються на цінах: \\
\hline Процентні ставки (Yields) U & $\mathrm{Tr}$ & $\mathrm{Tr}$ & $\mathrm{U}$ \\
\hline Процентні ставки (Yields) ff & $\mathrm{U}$ & $\mathrm{U}$ & $\mathrm{Tr}$ \\
\hline Залежність за опціонами, що базуються на прибутковості: & $\mathrm{U}$ & $\mathrm{Tr}$ \\
\hline Процентні ставки (Yields) U & $\mathrm{Tr}$ & $\mathrm{U}$ \\
\hline Процентні ставки (Yields) ff & $\mathrm{A}$ & $\mathrm{U}$ \\
\hline
\end{tabular}




\section{Herald of Lviv University of Trade and Economics. Economic Sciences. № 65, 2021}

Для ефективного управління ризиками за валютними опціонами необхідно знати особливості валютного ринку, оскільки валютний курс може бути вільно плаваючим або знаходитися під впливом дії офіційних та неофіційних контрольних та регулятивних механізмів, які запроваджує уряд. Незважаючи на оголошене “вільне плавання", офіційна влада не завжди дозволяє національній валюті обертатися незалежно від впливу ринкових сил, тому використовуються різні способи впливу на курс національної валюти. Це спричиняє ризик у процесі торгівлі валютними опціонами, оскільки ці заходи можуть викликати різку зміну курсу або сприяти встановленню курсу валюти, відмінного від ринкового.

Розрахунки в процесі виконання валютних опціонів істотно відрізняються від ідентичних процедур із іншими видами опціонів. Так, на Чиказькій біржі опціонів вони здійснюються через Опціонну клірингову корпорацію, яка затвердила спеціальні розпорядження, які дозволяють їй приймати та постачати кожну базисну іноземну валюту в країні походження для задоволення вимог щодо виконання опціонів. Клірингові співробітники зазвичай поставляють або отримують іноземну валюту на четвертий робочий день після виконання, який повинен одночасно бути банківським днем для банку - кореспондента Опціонної клірингової корпорації в країні походження [14].

Останнім часом набули досить широкого поширення розрахункові валютні опціони. Вони виражені у доларах США та є європейськими [14]. Кожен розрахунковий валютний опціон завершується не пізніше від двох тижнів після початку торгів по опціону. Розрахункові опціони $з$ довшим терміном планується провести у майбутньому. Розмір контракту розрахункового валютного опціону визначається кількістю базисної валюти, що покривається опціоном.

Виникнення екзотичних опціонів відбувається внаслідок специфічних вимог та інтересів інвестиційних банків. Їх активними учасниками виступають хедж-фонди та вони відіграють вирішальну роль на світовому ринку капіталів. Результатом виразу цих потреб стала поява у 1993 році бінарного опціону з подвійним бар'єром. За ним виплачується фіксована сума, якщо вартість активу залишається у межах окресленого опціоном коридору, або не виплачується, якщо ціни хоч раз виходять поза його межі [10].

Висновки i перспективи подальших досліджень у даному напрямі. Проведені дослідження дозволяють констатувати, що структура опціону має наступні характеристики: 1) базис, який складає основу опціону; 2) розподіл та співвідношення прав, обов'язків та ризику для контрагентів в опціоні; 3) зміст формальних та юридичних контрактів учасників; 4) правила строків виконання до завершення опціону; 5) режим нарахування та виплати премії 6) участь у торговому обороті на біржі та поза біржею; 7) особливі підходи до визначення вартості (цін) опціону, а також прийняття рішень щодо термінів виконання.

У цілому можна констатувати, що в Україні поки що активно застосовуються тільки спотові, форвардні, ф'ючерсні та своп угоди. Вітчизняний строковий валютний ринок знаходиться ще на стадії формування, хоча отримав у своє розпорядження сучасні інноваційні фінансові інструменти та фінансові технології. Звісно, для українського ринку ще недостатньо передумов для застосування складних видів фінансових деривативів - нових синтетичних інструментів, таких як “стредли”, “стренги”, спреди “биків” та “ведмедів”, а також спреди “метелик”. Всі ці похідні інструменти рекомендуємо застосовувати для зміни характеристик ризику та прибутковості існуючої позиції за допомогою методу портфельного страхування.

У подальших наукових дослідженнях необхідно сконцентрувати увагу на розробку стратегічних напрямів розвитку ринку фінансових деривативів, зокрема розширення інструментарію строкового ринку та посилення нормативноправового регулювання.

\section{ЛІТЕРАТУРА}

1. Солодкий М. О. Біржовий ринок : навч. посіб. для студ. вищ. навч. закл. К. : Аграрна освіта, 2010. 565 c.

2. Офіційний сайт Національної комісії 3 цінних паперів та фондового ринку. URL: https://www.nssmc.gov.ua/.

3. Офіційний сайт Агентства з розвитку інфраструктури фондового ринку України. URL: https://smida.gov.ua/about.

4. Сохацька О. М. Біржова справа : підручник. Тернопіль : Наукова думка, 2014. 656 с.

5. Шелудько В., Вірченко В. Сучасні тенденції розвитку світового ринку деривативів. Бюлетень Київського університету імені Тараса Шевченка. Економіка. 2014. № 10(163). C. 81-87. URL: https://cyberleninka.ru/article/n/suchasni-tendentsiyirozvitku-svitovogo-rinku-derivativiv/ viewer.

6. Зельдіс В. В. Біржовий ринок фондових деривативів в Україні та світі. Науковий огляд. 2015. T. 4. № 14. URL: https://www.naukajournal.org/ index.php/naukajournal/article/view/458.

7. Колодізєв О. М., Коцюба О. В. Аналіз перспектив розвитку ринку деривативів в Україні 3 урахуванням вирішення проблеми його нормативно-правового регулювання. Проблеми економіки. 2016. № 1. C. 242-248.

8. Шевченко О. М., Шевченко О. О. Сучасні тенденції функціонування ринку деривативів в Україні. Інфраструктура ринку : електр. фах. наук.практ. журн. 2018. № 18. С. 9-15.

9. Коваленко Ю. М. Інституціалізація фінансового сектору економіки : монографія / НУДПСУ. Ірпінь, 2013. $608 \mathrm{c}$.

10. The WFE's Derivatives Report 2019: вебсайт. URL: https://www.world-exchanges.org/ourwork/articles/wfe- 2019-derivatives-report. 
11. Гапонюк М. А., Парандій О. В. Управління ризиками біржового ринку похідних фінансових інструментів : монографія. К. : КНЕУ, 2015. 238 с.

12. Управління безпекою фінансових установ : колективна монографія / М. І. Диба, А. В. Бєгун, О. В. Білошицький, Є. А. Поліщук. К. : КНЕУ, 2015. $486 \mathrm{c}$.

13. Сидоренко О. В. Необхідність державного управління у біржовій сфері: базові аспекти. Науковий вісник НУБіП України. Серія: Економіка, аграрний менеджмент, бізнес. 2012. Вип. 177 (4). C. 111-115.

14. Чиказька біржа опціон - Chicago Board Options Exchange. URL: https://finsovetnik.com/chicagoboard-options-exchange/.

\section{REFERENCES}

1. Solodkyj, M. O. (2010), Birzhovyj rynok : navch. posib. dlia stud. vysch. navch. zakl., Ahrarna osvita, K., $565 \mathrm{~s}$.

2. Ofitsijnyj sajt Natsional'noi komisii z tsinnykh paperiv ta fondovoho rynku, available at: https://www.nssmc.gov.ua/.

3. Ofitsijnyj sajt Ahentstva $\mathrm{z}$ rozvytku infrastruktury fondovoho rynku Ukrainy, available at: https://smida.gov.ua/about.

4. Sokhats'ka, O. M. (2014), Birzhova sprava : pidruchnyk, Naukova dumka, Ternopil', $656 \mathrm{~s}$.

5. Shelud'ko V. and Virchenko V. (2014), Suchasni tendentsii rozvytku svitovoho rynku deryvatyviv, Biuleten' Kyivs'koho universytetu imeni Tarasa Shevchenka. Ekonomika., № 10(163), s. 81-87, available at: https://cyberleninka.ru/article/n/suchasnitendentsiyi-rozvitku-svitovogo-rinkuderivativiv/viewer.

6. Zel'dis, V. V. (2015), Birzhovyj rynok fondovykh deryvatyviv v Ukraini ta sviti, Naukovyj ohliad,
T. 4. № 14., available at: https://www.naukajournal.org/ index.php/naukajournal/article/view/458.

7. Kolodiziev, O. M. and Kotsiuba, O. V. (2016), Analiz perspektyv rozvytku rynku deryvatyviv $\mathrm{v}$ Ukraini z urakhuvanniam vyrishennia problemy joho normatyvno-pravovoho rehuliuvannia, Problemy ekonomiky, № 1, s. 242-248.

8. Shevchenko, O. M. and Shevchenko, O. O. (2018), Suchasni tendentsii funktsionuvannia rynku deryvatyviv v Ukraini, Infrastruktura rynku : elektr. fakh. nauk.-prakt. zhurn., № 18, s. 9-15.

9. Kovalenko, Yu. M. (2013), Instytutsializatsiia finansovoho sektoru ekonomiky : monohrafiia / NUDPSU, Irpin', $608 \mathrm{~s}$.

10. The WFE's Derivatives Report 2019: veb-sajt, available at: https://www.world-exchanges.org/ourwork/articles/wfe- 2019-derivatives-report.

11. Haponiuk, M. A. and Parandij, O. V. (2015), Upravlinnia ryzykamy birzhovoho rynku pokhidnykh finansovykh instrumentiv : monohrafiia, KNEU, K., $238 \mathrm{~s}$.

12. Upravlinnia bezpekoiu finansovykh ustanov : kolektyvna monohrafiia / M. I. Dyba, A. V. Biehun, O. V. Biloshyts'kyj, Ye. A. Polischuk (2015), KNEU, K., $486 \mathrm{~s}$.

13. Sydorenko, O. V. (2012), Neobkhidnist' derzhavnoho upravlinnia u birzhovij sferi: bazovi aspekty, Naukovyj visnyk NUBiP Ukrainy. Seriia: Ekonomika, ahrarnyj menedzhment, biznes., vyp. 177 (4), s. 111-115.

14. Chykaz'ka birzha optsion - Chicago Board Options Exchange, available at: https://finsovetnik.com/chicago-board-optionsexchange/.

Стаття надійила до редакиіï 05 листопада 2021 року 